Adam Fałowski ๑

Uniwersytet Jagielloński, Kraków

adam.falowski@uj.edu.pl

Wiktoria Hojsak (1)

Uniwersytet Jagielloński, Kraków

wiktoria.hojsak@uj.edu.pl

\title{
Z ETYMOLOGII ŁEMKOWSKICH. CZ. IV ${ }^{1}$
}

Słowa klucze: etymologia, leksyka łemkowska

Keywords: etymology, Lemko vocabulary

\section{Кавеніти}

Znane tylko z jednego źródła, por. кавенimu ‘żyć marnie, wegetować w biedzie lub chorobie' (H).

- Być może pozostaje w związku z pol. kawęczeć, kawęczyć 'harować, biedować, ślęczeć nad robotą, marnieć od ciężkiego trudu, z biedy, niedomagać, chorować, kwękać' (SEBań I: 647-648; MSGP: 97) i słc. dial. kavenčat 'chorlavet', trpiet' na nieco; stažovat' sa' (SSN I: 757). Por. także brus. dial. кавенчыциа 'мучыцца, пакутаваць ад болю', 'пакутаваць з кім-н.' i in. (ESBM IV: 18), кавэнчыцица 'мучыцца перад смерцю’ i in. (ibid.: 22). Tak więc należałoby przyjąć następujący rozwój na gruncie łemkowskim: ${ }^{\star}$ кавенчыьти > кавеніти, со wydaje się mało prawdopodobne.

1 Cz. I zob. „LingVaria” 2018, nr 1 (25), s. 125-139, cz. II zob. „LingVaria” 2018, nr 2 (26), s. 221-239, Cz. III zob. „LingVaria” 2019, nr 1 (27), s. 261-277. Wkład współautorów jest równy i wynosi po 50\%. 
Etymologię pol. kawęczeć, kawęczyć starał się rozpracować A. Bańkowski, który napisał: „Niejasne (tylko stp.), może *ka-vęčěti (z ekspresywnym prefiksem $k a$-), od

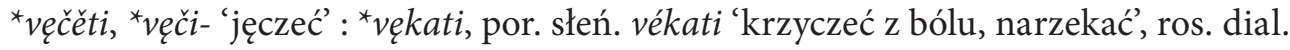
vjakats (i vjačatb) 'płakać głośno, szlochać, skomleć, szczekać itp.', czes. dial. věkati 'szczekać'; dalej niejasne” (SEBań I: 648). Do powyższych faktów należałoby jeszcze dodać ukr. dial. в'ячатu, в'якати 'мекати (про козу), пугати (про сову)' (ESUM I: 443) oraz brus. dial. вякаць, вячаць 'верашчаць, крычаць' (ЕSBM II: 300, 339), które to formy przez autorów wymienionych powyżej słowników etymologicznych uznawane są za formacje dźwiękonaśladowcze i łączone z ps. *ęčati 'wydawać żałosne dźwięki, jęki (pod wpływem bólu, cierpienia), narzekać, zwodzić, stękać, jęczeć, 'wydawać podobne dźwięki, o zwierzętach' (SP VI: 85-85).

Inny wywód narzuca łemk. (na Słowacji) kavuňiti 'kňučat' „Ps'atko cilu ňič kavuňilo" (AH), co zapewne należy wiązać z ukr. dial. кавучuти 'скавучати' zob. hasło скаву 'вигук, що відтворює виття собаки від болю, холоду', gdzie zamieszczono całą serię czasowników opartych na ps. dźwiękonaśladowczym * ${ }^{\star} k$ ovu (ESUM V: 260). Taki tok rozumowania, a więc przyjęcie rozwoju semantycznego: 'skowyczeć, skuczeć (o psie)' > 'jęczeć (o chorym człowieku)' > 'żyć w biedzie i chorobie' podtrzymują także fakty łemkowskie z Uścia Gorlickiego (pozyskane drogą ustną od H. Duć-Fajfer): сковынчати (пес сковынчыт) oraz ковынчати, кавынчати 'бідувати, жалити ся на біду'.

\section{Кавери}

Znajdujemy tylko w słowniku J. Horoszczaka: каверы 'nazwa terenowa' (H).

ESUM (II: 335) przytacza ukr. dial. (poleskie) кавер 'вир; коловорот', каверча 'вибоїна на дорозі' і czes. dial. kávjer 'драгва' (zob. także Machek: 246 - kávěr, gávěr, káděr, kaděr 'močal, bařina, močidlo, studánka pro dobytek, studánka s pitnou vodou (osazená kadłubem), malé jezírko'). Stosunkowo dobrze umocowane w polszczyźnie, por. stpol. dial. kawiór 'wir wodny (nad kamieniem albo pniakiem sterczącym na dnie rzeki)', nazwy miejscowe Kawiór 1318 w Małopolsce, później Kawiory 1400 (wieś nad Rudawą pod Krakowem; dziś ulica Kawiory w Krakowie (SEBań I: 648)), dial. (małopolskie) kawiorek 'snopek' (MSGP: 97), śląskie kowior 'mały staw lub dół z wodą' (ibid.: 111).

- ESUM (II: 335) widzi tu ekspresywny prefiks ka- oraz podstawę вер(u), związaną z вup (ps. *virz, ${ }^{*}$ vbrěti) lub вepmimu (ps. ${ }^{*}$ vbrtěti). Podobnego zdania jest A. Bańkowski ( ${ }^{\star} k a$-verı od ${ }^{\star} k o$-vbrěti). ESSJ (IX: 165) rekonstruuje ps. *kaverz 'wir wodny' wyłącznie na podstawie faktów czeskich i ukraińskich (bez polskich). 


\section{Кадивай, кадиваль}

Wyraz stosunkowo dobrze poświadczony w leksykografii łemkowskiej, por. кадьıвай 'куди', тадывай 'туди'; кадываль або кадывай = куда, куди (W), кади (кадываль) 'кудою' (В-H), кадивай, кадиваль 'куди' (Р1), кадиваль 'którędy' (Н).

Zbliżone formy występują na słowackim obszarze językowym, por. kadial 'kade' (KSSJ: 146), dial. kadial' kade, którym smerom' (SSN I: 733).

- Bazuje na ps. *kady 'gdzie, dokąd' (ESSJ IX: 111). Natomiast nie wyjaśniono jak dotąd końcowego elementu -вай, -валь (por. też łemk. всядиваль 'wszędzie' - H). L' Králik (s. 247) pisze: „Málo jasnou odvodeninou je kadial' (staršie kadel', kadiel')”. V. Machek (s. 305) wskazuje na niejasność -ва- w ukr. dial. тадивай, ros. откудова, mor. tedovaj, czes. indová. Podobnie: ESUM (II: 338).

\section{Карати ся}

Poczynając od I. Werchratskiego, czasownik ten w znaczeniu 'szczęścić się, udawać się, powodzić się’ zamieszcza większość znanych nam słowników łemkowskich, por. карати ся 'удавати ся, посчастити', не каре ся = не счастит ся, не веде ся, не викарало ся = не удало ся, także выкарати ся 'видати ся; удати ся' (W), каратися 'щастити', выкаратися 'вдатися, вдаватися, повезти, пощастити; вирости вдалим' (Р1), каратися 'щастити, таланити', выкаратися 'вдатися' (Р), карати ся 'darzyć się, выкарати ся 'udać się', „нич ся мі не каре” 'nic mi się nie udaje', „нияк ся мі не каре" 'zupełnie mi się nie wiedzie', „де ся такє выкарало” pejoratywnie 'gdzie toto się ulęgo' (Н), каратися 'щастити, таланити, нестися, плодитися (про тварин)' (Т), каратися 'вестися, удаватися' (Pr), wykaryty sia (Br).

ESUM (II: 387) cytuje wyłącznie za I. Werchratskim: dial. каратися 'удаватися, пощастити' (не кареся 'не щастить, не ведеться'; не викаралося 'не вдалося'). Znaczeniowo diametralnie odmienne ukr. каратися 'зазнавати моральних страждань; мучитися' (Hrincz II: 220-221; WTSSUM: 416), huc. karaty sy 'męczyć się' (J), bojk. каратися '(рогами) колотися', 'битися' (О).

- ESUM (II: 387) uznaje za niejasne. Trudno przyjąć, że mamy tu do czynienia ze specyficznym, wyłącznie łemkowskim rozwojem znaczeniowym ps. ${ }^{\star} k a-$ rati (sę) 'upokarzać, ostro napominać, strofować, łajać' (> 'wymierzać karę') (zob. ESSJ IX: 152-153; SEBor: 222). Raczej pożyczka, może związana z tur. kâr 'dochód, zysk; korzyść, pożytek'. Co do znaczenia 'męczyć się’ por. węg. kár 'szkoda, strata, niepowodzenie'. 


\section{Каренчыти}

Wyraz odnotowany jedynie w słowniku J. Horoszczaka: каренчыти 'karczować' obok карчыти і корчувати 'ts.' (H).

- Fonetyka (-ar- jako kontynuacja sonantu wobec wschodniosłowiańskiego -or-, por. корчувати) wskazuje na polski rodowód wyrazu, por. pol. dial. karczyć 'ts.' (Małopolska, okolice Nowego Sącza - z autopsji) < ps. *kzrčiti 'ts.' (ESSJ XIII: 201-210). Element -en- należy zapewne tłumaczyć kontaminacją z łemk. корень, коринь, корінь 'korzeń' (H).

\section{Каслик}

Tylko w niektórych źródłach łemkowskich znajdujemy ten wyraz, por. каслик, каслік 'тумбочка при ліжку' (P1; P), каслик 'rodzaj mebla - szafka z szufladą' (H), także накаслик 'нічна тумбочка при ліжку' (Р1), накаслик 'тумбочка біля ліжка' (P), накаслик 'тумбочка' (T), накаслик 'szafka przy łóżku' (Małastów - z autopsji).

Znane w gwarach ukraińskich, por. huc. накаслик 'тумбочка' (HH), buk. нахкаслик, нахткаслик заст., рідк. 'нічний столик, тумбочка' (SBH), naddniestrz. накаслик 'ts.' (S), gdzie zapewne z polskiego, por. pol. dial. nakastlik 'szafka nocna' (Małopolska, okolice Nowego Sącza i Krakowa - z autopsji). Tu zaliczymy także śląskie kastla 'skrzynka' (MSGP: 97), słc. dial. kastla (kasla) 'skriňa na uskladňovanie bielizne', kastlik (kaslík) 'poštová schránka' (SSN I: 755).

- Z niem. dial. Nachtkastel 'nocny stolik toaletowy', co składa się z Nacht 'noc' i Kasten, dial. Kastel 'skrzynia, skrzynka; komoda, szafa', Kästlein = Kästchen 'skrzyneczka, szkatułka, kasetka' (zob. ESUM IV: 53).

\section{Кєпешыти ся}

Odnotowano w nowszych słownikach łemkowskich, por. кєnещыти ся 'stroić się nadmiernie, paradować, puszyć się' (H), кепешьітися 'пишатися собою' (AP), кєпешығтися 'пишатися собою, гордувати', кєпешни 'гордий, пихатий, зарозумілий’ (Т), кєпєщний 'пихатий, зарозумілий’ (Pan).

Być może zaliczymy tu także zakarp. кепеш зневажл. 'неохайно, погано й дивно вдягнена людина; посміховисько' (Sab; SON). Dokładne paralele znajdujemy natomiast w gwarach słowackich, por. kepešit sa expr. 'vytahovat' sa, vystatovat' sa' (SSN I: 764), kepešic śe 'honosit' sa', kepešni 'pyšný' (Buffa: 121).

-Za pożyczką słowacką w łemkowskim przemawiają zarówno argumenty formalne, jak i semantyczne. Etymologia niejasna. Postulowany przez niektórych badaczy związek z ukr. кеn 'дурень', pol. kiер 'ts.', со z ps. dial. krрz 'vulva, cunnus' (SEBor: 
229) raczej mało prawdopodobny (jak objaśnić wtedy rozszerzenie o -eš-?), chociaż nie można nie zauważyć zbieżności semantycznych łemk. кєnещыıти ся z czes. dial. kepit se 'parádit se' (Machek: 249). Z uwagi na różnice fonetyczne i znaczeniowe trudno też postulować pokrewieństwo z ukr. копощuтися 'ворушитися, возитися; метушитися', dial. копишитися 'ts.; кишіти', ros. копощиться 'копошитиcя', przest. копышиться 'ts.' (ESUM II: 570), brus. разм. капашыцица 'шавяліцца, бязладна, мітусліва рухацца; корпацца, важдацца, капацца, будучы занятым якой-н. справай' (TSBM II: 628; ESBM IV: 248), со z ps. *kopošiti (sę) 'roić się, kłębić się; krzątać się, grzebać się, tożsamego z ${ }^{\star} k o p o s a t i ~ / ~ * k o p o s i t i$, intensivum na -s- od *kopati 'grzebać, ryć, wydobywać ziemię' (ESSJ XI: 23-24; SEBor: 248). Może jednak z węg. képes 'zdatny, zdolny (do czego)' ze zmianą znaczenia na 'hardy, zarozumiały', por. też rum. cápeş 'uparty, zawzięty' (WSRP: 118).

\section{Кіпнина}

Wyraz zamieszcza I. Werchratski: кіпнины 'Erdhaufen, Maulwurfshaufen’ „кіпнины повказували ся” (WU) i osobne hasło копень 'де сньіг скапал' „єдна копень” (ibid.) oraz J. Rieger w swoim słowniczku łemkowskim, por. kipnyna 'miejsce (w polu), na którym śnieg stajał', kipnynı wydno, kopiń, kittyna (?) (R). Występuje w kilku postaciach fonetycznych: кіплина, кітлина, кіпнина 'wygrzana na wiosnę od południowej strony pagórka płaszczyzna w śniegu, aż do trawy' (H), a także jako pluralia tantum: кіпнины 'місце навесні, де розтанув сніг' (В-Н; АР).

W gwarach ukr.: huc. кіпнина // кіпня 'місце, де розтанув сніг; проталина', кіпніти 'розтавати (про сніг)' (HH), kipnia 'pole, na którym śnieg się stopił’ || kipnyna, kipnity 'ginąć (o śniegu)', kipno 'gdy śnieg na drodze stopi się' (J). W słowniku B. Hrinczenki: кіпний, кіпна дорога 'грязная от растаявшего снега?', кіпнина 'кучка земли, поднятая кротом', кіпніти 'таять', кіпно 'потеплело, оттепель на дворе; грязно (от растаявшего снега)' (Hrincz II: 245). Powtarza to ESUM (II: 569). Dobrze zaświadczone w gwarach słowackich, por. kopnina (koplina) 'menšie miesto, kde sa rozpustil sneh; uschnuta zem po daždi'; kopniet' (kopeniet') 'ostávat' bez snehu, osychat' (o zemi na jar); topit sa, strácat' sa (o snehu na jar)'; kopno 'holo, bez snehu'; kopný 'holý, nepokrytý snehom; obschnutý, suchý' (SSN I: 823-824), oraz w gwarach polskich, por. małopolskie koplina 'miejsce, na którym śnieg się roztopił', kaszubskie kopnia 'miejsce bez śniegu; mroźna pogoda, gdy nie ma śniegu' (MSGP: 110).

- Derywat z sufiksem -yna. Por. ps. *kopsněti / *kopniti (sę) 'tajać, topić się (o śniegu)' pochodne od ${ }^{\star} k o p b n a /{ }^{*} k o p b n o /{ }^{*} k o p s n z$ 'dający się kopać, niepokryty śniegiem', przymiotnika od *kopati 'kopać' (ESSJ XI: 42-44). Motywacja semantyczna ujawnia się w znaczeniu czasownikowym 'tajać, topić się (o śniegu)' - ziemia, na której stopił się śnieg, jest zdatna do kopania. 


\section{Кырмак}

Sporadycznie trafia do słowników łemkowskich, por. кырмак 'abgebrochener Ast', кырмача 'Stöcke, abgebrochene Aeste, патичє' (WU), кырмак 'віл короткорогий раси швайцарскої' (ibid.), кырмак, мн. кырмаки, кырмача 'кусок палки, грубий патик' (Р1), кырмак 'грубий відламок палиці' (Р), кырмак 'kawałek suchej (raczej krzywej) gałęzi, raczej krótki’ (H).

Poza obszarem łemkowskim mamy do czynienia tylko z ukr. dial. кирмак 'кривий шматок дерева' (ESUM II: 436) i słc. dial. kirmák 'vôl s krátkymi rohami' (SSN I: 768; Buffa: 122).

- ESUM (II: 436) rozpatruje ukr. dial. кирмак łącznie z кирнак (zob. niżej). Analogiczną wymianę spółgłosek nosowych obserwujemy w podobnym na pierwszy rzut oka materiale białoruskim, por. brus. dial. кірматы 'крываногі', кірнаты 1. 'вілаваты, сукаваты', 'парны, з раздвоеным караняплодам', 'крываногі', кірнаты 2. 'невысокі', со odnosi się do rzeczownika кірна 'А-падобная прылада, сажань', 'тоўсты сук', 'раздвоены корань у караняплодах' (ESBM V: 38). Etymolodzy białoruscy widzą tu pożyczkę litewską, por. lit. kìnа 'корань дрэва' (ibid.), со można łączyć z lit. kēras 'pień, karcz, krzak' (zob. Smoczyński: 276-277), wszakże trudno zastosować taki punkt widzenia do faktów łemkowskich.

Zob. кырнак.

\section{Кырнак}

W tej postaci znajdujemy już u I. Werchratskiego, por. кырнак 'Stock, ein Stück Ast', кырнача gen. neutr. collect. = кырнакы (W), кырнаs 'Stock, abgebrochener Ast' „тельо мі кырнагів на яблінь наметаў, што гвалт: очалал вшыткы ябка” (WU), кырнал 'жердка, хабина' (Horb), кырнак, закыртаўленый, нисенито 'пуцьвірінок, знітеня' (ibid.), potem jeszcze tylko w słownikach P. Pyrteja: кыюннак 'кусок палки, грубий патик', кырнача 'патиччя' (P1), кырнак 'грубий відламок палиці', кырнача 'патиччя' (Р), кырнак 'krzak, krzew' (H).

ESUM (II: 436) przytacza wyłącznie za I. Werchratskim dial. кирнак 'палиця, патик', кирначчя 'паліччя'. Por. też nadsańskie курнак 'Baumstrunk' (WD).

- W ESUM (II: 436) czytamy: „неясне; можливо, видозмінене щодо словотвору і семантики запозичення з словацької мови (пор. krnáč 'кряж, колода, оцупок')". Należy przy tym zauważyć, że znaczenie wyrazu słowackiego zostało tu podane błędnie, por. słc. dial. krnáć 'křivé, sukovité dřevo, pařez, haluz' (Kálal: 275), krnáč 1. 'krivý strom'. 2. expr. 'vychudnutý stary človek' (SSN I: 882).

Formacja na -ak oparta najpewniej na ps. ${ }^{\star} k \varpi r n a t i,{ }^{\star} k$ krněti 'obcinać, odrąbywać; strzyc; skracać', ${ }^{\star} k z r n z(j b)$ 'obcięty, połamany; okaleczony, zniekształcony' (ESS) XIII: 230-231; 236), por. choćby ukr. dial. карнати 'пасти' (zapewne pierwotnie 'об- 
різувати; стригти' - ESUM II: 394), корняти 'колоти, бити; підганяти; доторкатися, будити; спонукати' (ESUM III: 33).

Interpretacji wymagają fakty rumuńskie, por. rum. cârn m.in. '(o przedmiocie) krzywy', cârní 'skręcać; zakręcać; zawracać', roln. 'podcinać (pędy)' (WSRP: 135).

Zob. кырмак.

\section{Кыртавый}

Wyraz bogato udokumentowany w leksykografii łemkowskiej, por. кыртавыц 'verkümmert', кыртаве дерево 'verkümmert Baum', кыртавеи, 'kleiner, verkümmerter Mensch' (W), кертак dem. кертачок 'Zwerg, Krüppel' (WU), кырнак, закыртаўленый, нисенито 'пуцьвірінок, знітеня' (Horb), кыртавий 'погано розвинута рослина, переважно дерево' (В-Н; АР), квіртавіти 1. 'не рости, припинити ріст'. 2. 'не розвиватися, ледве жити' (АР), кыртавий 'покривлений, покорчений, недорослий', кыртавеи 'мала незграбна людина', кыртавіти 'недоростати, корчитись' (Р1), кыртаве нр. дерево 'karłowate coś, źle rozwinięte, niedorośnięte, nieproporcjonalne, np. drzewo', кыртавеu, 'ktoś mały, nieproporcjonalnie gruby w stosunku do wzrostu, lekko skarlały' (H), киртавий 'скарлючений' (Pan).

Jeszcze tylko u Bojków stykamy się z podobnymi formacjami, por. кupmaвimu 'нидіти', киртак 'мала, нерозвинена людина', 'недоросток' (O). ESUM (II: 437) podaje wyłącznie za I. Werchratskim: киртавий 'скарлючений', киртавець 'невелика скарлючена людина'. Nie można wykluczyć, że należy tu także ukr. dial. кирдатий 'людина з великим носом, догори задраним; курносий', кирдичка 'мала на зріст жінка, людина', кирдя 'тс.' (ibid.: 435).

- ESUM uznaje za niejasne, wskazując przy tym na możliwość powiązania z słc. krt 'kret' (łemk. кыртиия 'ts.' - H). Jest w tym sporo racji, kiedy weźmiemy pod uwagę słc. dial. krt 1. 'Talpa'. 2. 'velmi malý človek' (SSN I: 889). Rozwój znaczeniowy: 'kret' > 'ktoś (coś) mały, skarlały’ może być powodowany faktami słowackimi.

\section{Кыявчати}

Wyraz dość słabo znany. Występuje w słowniku I. Werchratskiego, por. кыявчaти 'knurren', кыявчит в кышках 'es knurrt im Magen (in den Gedärmen)' (W), powtórzony następnie przez J. Horoszczaka, por. кыявчати 'burczeć $\mathrm{w}$ brzuchu, z przejściem w pisk’ (H). Uwzględnia go także P. Pyrtej, por. кыявчатu 'бурчати' (P1).

Podobne czasowniki onomatopeiczne w gwarach łemkowskich oznaczają odgłosy ptaków, por. np. кіявкатu 'krächzen (von Dohlen)' „кавкы кіявкают або 
кіявчат" (WU), powtórzone u Hrinczenki, por. кіявкати, кіявчати 'кричать (о галках)' (Hrincz II: 247).

- Prawdopodobnie wymieniony czasownik ma genezę dźwiękonaśladowczą, na co wskazuje ESUM (II: 452), zestawiając go z ukr. кавкати, кавчати розм. 'видавати звуки, схожі на „кав-кав”; вищати, пищати; каркати’ (WTSSUM: 409).

\section{Клапец}

W tej postaci poświadcza tylko J. Horoszczak, por. клапеu 'część odzieży zwisająca luźno, patka', a obok tego także клапmaвe 'luźno zwisające', клаnтатu 'dyndać, luźno zwisać' (H). Poza tym: kłapok 'wypustka ( $15 \mathrm{~cm}$ długa), przy huńce były cztery' (R), клапиі l. mn. 'zwisające u dołu elementy tradycyjnego gorsetu, kaletki' $\mathrm{z}$ autopsji, клапавый 1. 'клаповухий'. 2. 'обвислий', клаптавий 1. 'клаповухий'. 2. 'який ходить похитуючись' (Pan).

Zapewne zaliczymy tu rozbudowane semantycznie bojk. клапець 1. 'хлястик на рукавах'. 2. 'клапан над кишенями'. 3. ‘зубці корсета'. 4. 'лацкан кофти або піджака'. 5. 'язичок черевика'. 6. 'шматок будь-ного', клапчастий 'обвислий’ (O), huc. клапатий (клепатий, клипатий) 'клаповухий' (НH), kłapatyj 'kłapouchy' (J), buk. клапатий 1. 'розпатланий’. 2. 'нестрижений, з довгим волоссям'. 3. 'клаповухий' (SBH), zakarp. клепавый 'з одвислими вухами' (Sab; SON), ukr. dial. клап 'зубець в одязі; наушник у шапці', клапи 'вуха свині', клаптавий 'обірваний, у клаптях' (ESUM II: 454), pol. dial. kłapcie 'wyłogi albo klapy u kożucha, sukmany', kłapaty 'mający wielkie uszy, kłapouchy', kłapciasty, kłapciaty, kłapiasty, kłaptawy 'obwisły, zwieszający się, ochlapły', kłapciawy, kwapciawy 'wielki, wiszący (o uszach)' (SW II: 368-369), słc. dial. klapta 1. 'širší golier na kabáte’. 2. 'látka sformovaná na odeve obyč. do podoby krídelka', klaptavý expr. 'ovisnutý; klaptaviet' (kleptaviet') expr. 'vädnút', stávat' sa ovisnutým (o rastlinách)' (SSN I: 773).

- Można przyjąć, że „krawieckie” znaczenie wyrazu ma swoje źródło w niem. Klappe 'klapa, przykrywka; wyłóg (u kieszeni)', podobnie jak pol. klapa 'wyłóg' (SEBań I: 686), natomiast znaczenie 'luźno zwisający, obwisły' (клапавий) opiera się

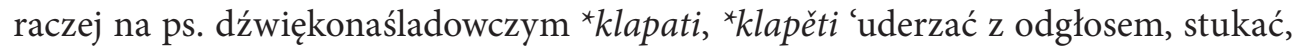
pukać, szczękać' (ESSJ IX: 184-185; SEBor: 237) z rozszerzeniem o -t- (клаптавиŭ, клаптати). Zdaniem autorów ESSJ wyrażonym pod hasłem ${ }^{\star} k$ lapa w pewnych sytuacjach prawie niemożliwe jest ustalenie, czy mamy do czynienia z kontynuacją formy prasłowiańskiej, czy niem. Klappe (ibid.).

Zob. клаптош. 


\section{Клаптавий, клаптати zob. клапец}

\section{Клаптош}

Zasadniczo w tej postaci występuje tylko u I. Werchratskiego, por. клапmom 'Schnappmesser' (W). Za nim powtarza J. Horoszczak, odsyłając do кляпач 'scyzoryk bez sprężyny utrzymującej ostrze w pozycji wyprostowanej, kozik, którego ostrze „klapie” (H), co jest nazwą powszechną u Łemków (też клanau) w znaczeniu 'складаний ніж з дерев’яною ручкою' (WU, B-H; AP; P1; P; T). O. Horbacz w tymże znaczeniu 'складаний ножик з дерев’яною ручкою' podaje wyraz клепач (Horb).

W źródłach ukraińskich sygnowane jako wyłącznie łemkowskie, por. клanmou 'складной нож' (Hrincz II: 248; ESUM II: 454) w przeciwieństwie chociażby do bojk. клапак, клапаник 'ts.' (O). W gwarach słowackich identyczna co do struktury ekspresywna forma klaptoš (= klapták) znaczeniowo całkiem odmienna od łemkowskiej ('nešikovný človek'), por. też kl’apta 'nešikovná žena', kl’aptavý expr. 'nešikovný, komu všetko pada z ruky', znaczeniowo wtórne wobec klaptavý expr. 'ovisnutý' (SSN I: 773).

- ESUM (II: 454) traktuje jako niejasne zarówno клаптош 'складаний ніж', jak też клапач, кляпач 'вид ножа'. Zapewne derywat z sufiksem -ou od czasownika łemk. клапmamu 'dyndać, luźno zwisać' (H). Być może inspirowane semantycznie przez niem. klappbar 'składany', Klappmesser 'nóż składany, scyzoryk, kozik', klappen 'klapać, zamykać się z hałasem'.

Zob. клапец.

\section{Клеветати}

Tylko w słowniku J. Horoszczaka widnieje: клевет 'klekot', клеветаня 'klekotanie', клеветати 'klekotać', a także (oddzielnie) клеветати w znaczeniu 'paplać, opowiadać niepotrzebnie rzeczy powierzone w zaufaniu’ $(\mathrm{H})$.

Onomatopeiczny charakter czasownika widoczny jeszcze tylko w buk. клевтаmи 'клепати' (SBH). Ukr. dial. formy клевета 'наклеп', клеветня, клевота 'тс.', клеветуха 'балаклива, сварлива жінка (?)', клеветатися 'базікати; сперечатися' (Hrincz II: 249; ESUM II: 456) znaczeniowo zbiegają się z ros. клевета, клеветать, сzes. kleveta, klevetit, słc. klebeta, klebetit', scs. клевета, клеветати, ps. ${ }^{\star} k$ kleveta, ${ }^{\star} k$ klevetati (ESSJ X: 14-17).

- Jeśli założymy, że dźwiękonaśladowcze znaczenie łemkowskiego czasownika jest archaiczne (prymarne), to jego rozwój semantyczny mógł podążać takim torem: 'klekotać' > 'paplać, plotkować' > 'obmawiać, oczerniać. Przybliżymy się tym samym poważnie do rozwiązania genezy tego zagadkowego wyrazu, która mimo 
bogatej literatury wciąż nie została wyjaśniona w sposób zadowalający (zob. ESSJ X: 14-17; ESUM II: 456; SEBań I: 712; Králik: 267). Rzeczownik należy uznać za wtórny wobec czasownika.

\section{Ключы}

W takiej postaci (nagłosowe $k$-) jako pierwszy podał I. Werchratski, por. ключu, клyча 'Lunge' (W), a po nim P. Pyrtej: ключы 'легені в людини' (P1) і J. Horoszczak: ключь 'płuca' (H).

- Zapewne chodzi o postać *nлючbl, z zamianą nagłosowej spółgłoski, por. plucza, l. poj. pluczo 'płuca', pluca (R), nлюu, 'Lungen' z odniesiem do czes. plíce, pol. płuca (WU), пл'уu, 'легені' (Horb), плюи а 'легені' (Čiž), pluca 'płuca' (Bar). Podobna zamiana nagłosowego $p$ - w $k$ - u Łemków: kludek, klutyk - pludyk 'osa cívky součást člunku tkalcovského stavu' (Šiš).

\section{Кобан, кобаня, кобиця}

Według danych J. Riegera najbardziej rozpowszechnionym spośród trzech wymienionych wariantów słowotwórczych jest kobycia, kobicia 'pieniek do rąbania drzewa' (R). Por. także: кобич'а 'нога лавки; купка ріща, хмизу (рідж'а рубавуд’ на кобиц'i)' (Horb), кобиия 'кусок дерева, довжиною 1 м, на якому колять дерева' (В-Н; АР), kobica 'klada na štiepanie dreva' (AН), кобиця 'кусок деревини, що служить місцем для рубання дров' (P1), кобиия, пнячок 'pieniek do rąbania drewna' (H), кобиия 'дерев’яна колода, на якій рубають дрова' (Т), kovbyc'a ‘špalek na štípání dřiví' (Šiš). Znacznie rzadziej spotykane są dwa pozostałe warianty, które odnotował jedynie P. Pyrtej, por. кобан 'рівно зрізана деревина з двох сторін, на якій можна що-небудь тесати', кобаня 'козел - пристрій, на якому роблять колеса' (Р1; Р).

$\mathrm{W}$ gwarach ukraińskich znajdujemy liczne egzemplifikacje wymienionych formacji, por. bojk. ковбан 'колода для рубання дров', 'кусок дерева, обрубок, який підкладають під ніжки ліжка, скриню', ковбиия 1. 'колода для рубання дров’. 2. 'колода під ковадло'. 3. 'сувій біленого полотна' (O), huc. ковбан // ковбок 'відрізаний кусок дерева; колода; пеньок, на якому рубають дрова' (НH), kowban \| kuban 'pieniek, ucinek do rąbania na nim drzewa', kowbok 'kloc ok. 6 m długi, ucięty grubszy koniec pnia świerkowego' (J), buk. ковбан 'згруб. до ковбок', ковбок, кобок 1. 'колода, чурбан'. 2. 'пень'. 3. жарт., перен. 'товстун' (SBH), naddniestrz. кобан, ковбан, кубан 'колода, на якій рубають дрова', ковбииє 1. 'ніжка лави, ослона'. 2. 'колода, на якій рубають дрова'. 3. 'дерев’яна підставка для ковадла' (S). ESUM (II: 479-480) pod hasłem ковбан 'колода, на якій рубають дрова; короткий товстий оцупок дерева замість табурета; колода, чурбак, пень' wymienia szereg in- 
nych formacji dialektalnych, por. ковбик 'чурбак, колодочка (дерев’яна)', ковбиия 'колода, на якій рубають дрова; підпора, стояк (глиняний) для лави', ковбок 'товстіша частина дерева, відрізана від вершини; пень; колода, чурбак', ковбон 'колода, чурбак' (zob. także: Hrincz II: 260-261; WTSSUM: 437).

Pol. kowbica 'podpora wkopana w ziemię dla osadzenia ławki' prawdopodobnie z ukraińskiego (SW II: 508).

- ESUM (II: 480) wskazuje na związek z ukr. i ros. колобок 'невеликий круглий хлібець', wszakże pod hasłem колобок сzytamy, że to zbliżenie ma charakter wtórny (ibid.: 515-516). Wszystkie trzy warianty zapewne należy odnieść do prasłowiańszczyzny, por. ${ }^{\star} k z l b a n ヶ$ / ${ }^{\star} k$ źlban'a, ${ }^{\star} k z$ lbica 'pień, kłoda do rąbania drew' < $<{ }^{\star} k$ z lbati, ${ }^{\star} k \approx l b r$ 'coś wypukłego, napchanego, kłębiastego' (ESSJ XIII: 178, 180-182; SEBor: 229). Da się być może sprowadzić do pierwiastka ${ }^{\star}(s) k e l b-/{ }^{*}(s) k o l b$ - 'ciąć, rąbać' (ESSJ XIII: 178, 180-182).

\section{Ковырдати}

W tej postaci znajdujemy wyłącznie u J. Horoszczaka: ковырдати 'przewracać bezceremonialnie z boku na bok' $(\mathrm{H})$.

Możliwe, że należy rozpatrywać razem z ukr. dial. кувирдь 'беркиць', ros. dial. кувырдаться 'перекидатися', кувырдать 'кидати палицю' (ESUM III: 121), кувырдаться 'кувыркаться', кувырдыши, -дышкимн. и нар. 'кувырок, кувырком перекувырышки' (Dahl II: 211), кувердать 'трясти, двигать' (Vasmer II: 397).

- ESUM (III: 121) traktuje ukr. dial. кувирдь jako zapożyczenie z języka rosyjskiego. Wyróżnia prefiks $\kappa y$ - oraz tematyczne -вырдать, zestawiane z sch. врдати 'уклоняться, избегать' (zob. Vasmer II: 398). ESSJ (XIII: 142) wyłącznie na podstawie rosyjskich danych dialektalnych rekonstruuje ps. czasownik ${ }^{\star} k u v b r t a t i$ se

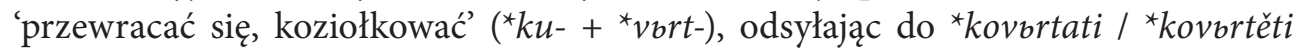
'dłubać; wiercić' (ESSJ XII: 18), co odpowiada ukr. dial. ковертати 'направляти, керувати, правити, повертати’ (ESUM II: 483).

\section{Конда, кондя}

Wyraz dobrze udokumentowany w leksykografii łemkowskiej, por. кон'm’ŏ, -ова 'жіноча фризура: гудз з волосся' (Horb), кондя 'завинуті в круг волосся на голові жінки' (В-Н; АР), контя 'заплетена і закручена на голові коса в заміжньої жінки' (P1; P), конда, кондя 'rodzaj uczesania (kok) lub brzydka budowa głowy $\mathrm{z}$ wystającą potylicą' $(\mathrm{H})$, konta 'ženský účes z vrkočov stočených na zátylku' (AH), konta 'drdol, uzel $z$ vlasů vázaný v týle - tradiční účes vdané ženy' (Šiš), u Rusinów Wojwodiny контьа 'чепець, зад голови’ (Hn). 
Obecny w gwarach zakarpackich, por. кôнm'a, кôн'm, sôн'm' 'заложенная коса (у женщин)' (Łyzanec': 6о4), конті 'шиньйон' (Sab). ESUM (II: 556) przytacza w postaci конти (мн.) 'вузол волосся в угорських жінок'. Bardzo żywotny w gwarach słowackich: kont (koňt', chont) 'ženský účes z vrkoča stočeného na zátylku do uzla; drdol'; kont’a (koňta, konča) 'ženský účes z vrkočov stočených na zátylku' (SSN I: 816).

- Z węg. konty 'kok'.

\section{Копырдати ся}

Czasownik ten występuje w dwóch wariantach fonetycznych: копьрдатіс'а 'копорсатися, неспокійно лежати (дитина)' (Horb), копырдати ся żart. 'przewracać się' (H), копьрднутися 'перекинутися, впасти від удару' (Т), skopyrdaty sja expr. 'privest' na svet nemanželské dieta' (AH) і копиртатися 'перевертатися, перекидатися' (Р1), копьртатися 'беркицяти, перекидатися через голову; падати' (Р). Poza tym należą tu także zapewne pochodne od czasownika (z wtórnym znaczeniem seksualnym): kopsırnak (kopyrnak) 'nieślubne dziecko', kopsırdan, kopsırniak: kopyrniak 'ts.', kopsırdaja 'dziewczyna mająca nieślubne dziecko' (R), копьрдя 'nieślubne dziecko', копьцдяр 'ktoś z nieślubnego łoża' (H), kopyrda expr. 'žena majúca nemanželské dieta' (AH) oraz inne formacje zawierające tenże pierwiastek: nonııтаний 'porąbany”, głupi i narwany' i być może oдnьцияти ся żart. 'obronić się przed kimś natrętnym, spowodować „odczepienie się”” (H).

ESUM (II: 567) zalicza tu również ukr. dial. копирснути 'швидко впасти, полетіти сторч головою'.

Odpowiedni materiał gwar polskich zaskakuje obfitością i różnorodnością, por. chociażby kopyrtać, kopyrtnąc 'umrzeć, wyciągnąć kopyta', kopertać 'kręcić, przewracać, rzucać', kopyrtać się, kopertać się 'kręcić się, przewracać się, wywracać koziołki, rzucać się, pluskać się', kopertki, kopyrtki 'koziołki', koperlić się, kopyrlić się 1. 'być niespokojnym'. 2. 'żenić się', koperdak, kopyrdak 'kobieta brzydka a lubiąca się stroić, czupiradło, koczkodan, straszydło’ (SW III: 465-466), kopyrtnąć się 'przewrócić się, fiknąć koziołka' (MSGP: 110). Por. też podkrakowskie (Bronowice Wielkie) przezwisko Skopyrda (z autopsji). A. Brückner widzi tu związek etymologiczny z ludową (myśliwską) nazwą zająca, por. kopera, kopyra 'zając' (SEBr: 255). Bez prefiksalnego ko-: perda, pyrda 1. 'świnia'. 2. 'przezwisko dziewuchy', perdać, pertać 'biegać drobnym krokiem, dreptać', pertnąć, pyrtnąć 'trącić, szturchnąć', pertek 1. 'człowiek drobno chodzący'. 2. 'człowiek drobny' (SW IV: 113, 119; SW V: 449), popyrciany 'zawsze prędki' (SW IV: 694), popyrtany 'roztrzepany, prędki i chaotyczny' (MSGP: 208), pyrtać 'popychać, trącać' (ibid.: 234), pyrtek 'mały drobny chłopiec' (z autopsji), także nazwisko Pyrtek. Podobną sytuację obserwujemy w gwarach słowackich, por. kopŕdat' sa expr. 'válat' sa, povalovat' sa', koprd 'kotrmelec', koprdanec 
i koprdenec 'kotrmelec', kopŕcat' sa 'gúlat' sa, robit kotrmelce'. 2. expr. 'hynút, kapat', koprickat' sa expr. 'gúlat' sa, válat' sa, robit kotrmelce', kopŕlat' sa expr. 'mrvit' sa, prevalovat' sa (o dietati v perinke)' (SSN I: 824-825), kopirdan 'nemanželské dieta' (ibid.: 823), kopirdan, koperdan, kopirdaňec, kopirdant 'ts.' (Buffa: 131), por. także słc. dial. kobŕcat' sa, kobŕnat' sa 1. expr. 'kývat' sa z boka na bok'. 2. expr. 'potkýnat' sa'. 3. expr. 'válat' sa, gúlat' sa' (ibid.: 792), czes. kobrtat' ekspr. 'potykać się' (SCP: 232), škobrtat pot. ekspr. 'kuśtykać, kusztykać, potykać się' (ibid.: 779; Machek: 264).

- Nie do końca jasne. Prawdopodobnie składa się z prefiksu $\left.\kappa^{*}-{ }^{*} k o-\right)$ i tematu ps. czasownika * prrtati 'pchać, popychać' (por. pol. dial. pertać, pyrtać 'ts.') (SESł II: 458-459; ESUM II: 567; Králik: 289). Próby A. Bańkowskiego kojarzenia z pol. dial. pyr(s)tać = ${ }^{\star}$ parstać 'szturchać palcem' od stpol. parst 'palec' całkiem chybione (SEBań II: 531).

\section{Коцюрба}

Powyższy fitonim udokumentował już I. Werchratski, por. коцюрба, кочурбина, кочурба 'Traubenkirsche, Ahlkirsche, Prunus padus' (W), коцьірба, коцьірбина 'Traubenkirsche, Prunus padus, котерба' (WU), a po nim inni: kocirba і kocierbina 'czeremcha', kociurba, kociurubka, kuсигуba itp. (R), коиірба 'черемха' (P1), кочербина 'czeremcha' (H).

W słowniku B. Hrinczenki przytoczono wyłącznie za I. Werchratskim: коц̧юpба 'черемуха, Prunus padus' (Hrincz II: 295). S. Makowiecki w większości także oparł się na I. Werchratskim, por. kocirba, kocirbyna, kocurba, kočurba, kočurbyna 'Prunus padus' (Makowiecki: 300; ESUM III: 65). W licznych wariantach nazwa ta występuje w gwarach polskich, np. kocierba, kocirba, kociurba, korciupka, kurcipka, kocierzba, kucipka 'Prunus padus a. Cerasus padus' (SW II: 387), kocierba, korcipa 'czeremcha' Mp, kurcipa, purcipa 'ts.' Mp pn (MSGP: 106, 119), a także słowackich, np. kotrbina (kocierbina) 'kert tŕpky, bot. čremcha (Padus)', kotŕbka (kocerpka, kocierpka) 'plod tŕpky' (SSN I: 847).

- ESUM (III: 65) traktuje jako polonizm w ukr. znane już w stpol. w dwóch wariantach: kocirpka // pocirpka (1472) 'jagoda czeremchy'. A. Bańkowski proponuje jako punkt wyjścia po-cirzpka (jagoda) 'jagoda trochę cierpka' w opozycji do bardziej cierpkich jagód tarniny lub dzikiej porzeczki (SEBań I: 742). (O późniejszym zastąpieniu prefiksu po- przez ko- zob. ibid.: 733). 


\section{Кракоч}

Widnieje tylko w łemkowskich słownikach I. Werchratskiego, por. кракоч 'Küchenschabe, Periplaneta orientalis' (W), кракоч 'ts.' (WU), co powtarza J. Horoszczak: кракоч 'karaluch' (H).

B. Hrinczenko zamieszcza кракоч 'таракан, Periplaneta orientalis' za I. Werchratskim (Hrincz II: 298). Podobnie ESUM (III: 73).

- ESUM uważa za niejasne. Być może należy wiązać z buk. крак 'гілка', краканка 'ts.', краканатий, краканастий 1. 'гіллястий'. 2. 'кривоногий'. 3. 'довгоногий', кракани 'пристрій для пиляння дров, козли', кракатий 'гіллястий' (SBH), со przejęto z języka rumuńskiego, por. rum. crac 'gałąź', ale też 'podudzie; nogawka, nogawica', crácă 'gałąź, konar', crăcán, crăcánă 'widlasta, rosochata gałąź, widły'

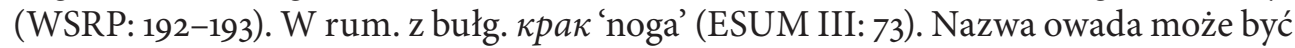
związana z długimi czułkami przypominającymi rozwidloną gałąź lub też z długimi, rozkraczonymi nogami. Niejasne wszakże końcowe -oč.

\section{Кужівка}

Wyraz dobrze poświadczony na terenie Łemkowszczyzny, кожілка 'припоясова кушка тримати брусок до коси' (Horb), kużiwka, kużywka 'pochewka na osełkę do ostrzenia kosy (i na wodę)', kożywka, kożuwka, kużka 'ts.' (R), кужівка 'футляр, куди клали камінець (дурбак) для гостріння коси’ (В-Н; АР), козівка (кузівка) 'металевий або дерев'яний футляр для бруска, який носят з водою на поясі при косінні трави або зернових', кужывка, кужівка 'деревяна або металева коробочка для води, камінного бруска, причіплена до пояса; служить при косінні' (P1), кужывка, кужівка, кожівка, козівка 'металевий або дерев'яний футляр, наповнений водою, в якому носять брусок для клепання коси' (Р), кужывка, кужівка, кузбівка 'pojemnik na osełkę, najczęściej z rogu bydlęcego, czasem z blachy' (H), куживка 'футляр (найчастіше з рога), у якому косарі носять брусок з водою' (Т), kužilka 'pouzdro na brousek zavěšéne v pase’ (Šiš).

ESUM (III: 125) uwzględnia ukr. dial. кужилка 'посудина, в яку косарі вкладають мантачку', a także козівка 'чашка, миска; початок кукурудзи' (ESUM II: 50o). Por. też słc. dial. kužilka 'oselník' (Buffa: 144).

- ESUM (III: 125) odsyła do synonimicznego кyuкa 'ts.', które nie posiada jednolitej etymologii (por. ibid.: 170; SEBań I: 863). Postać козівка zdaje się wskazywać na związek z коза (z uwagi na to, że początkowo kosiarze używali do wymienionego celu rogów zwierząt domowych), por. także pol. dial. kózka (obok kószka, kuszka) 'schowek drewniany na osełkę, zatykany za pas kosiarza; małe naczyńko do wody, potrzebnej kosiarzowi przy ostrzeniu kosy' (SW II: 519) oraz kózaj 'drewniana pochewka na osełkę' (SGM I: 148). Por. także komentarz znaczeniowy do huc. kuszka 'kózka, naczynie na osełkę do kosy' (J). 


\section{Курділь}

Dokładną charakterystykę wyrazu znajdujemy w słowniku I. Werchratskiego: $\kappa y p-$ дель, лем г водьі курдель 'По думці люда, хробак, що споводує у худобы хороту звану також „курдель”, курділь, курдьіль зальічити (W). Rozwinął ją J. Horoszczak: курділь, курдель 'według dawnych wierzeń cieniutki biały robaczek, znajdujący się w wodzie, który podobnie „właził w język”, gdy się piło wprost z potoku - powodując opuchliznę języka. Ponoć można go było „zaczytać”, znając tajemne formułki. Według niektórych wierzeń, zjadał język' $(\mathrm{H})$. W innych źródłach skromnie, por. курдел ' кордюк, чиряк на язиці в товару' (Horb), kurdil 'kurdziel' (Fal), курділь 'черв'ячок, який викликає хворобу язика у тварин (з'їдає язика)' (B-H; AP). Zupełnie co innego: курдель, курділь 'курдюк; жирове відкладення біля хвоста у деяких порід овець' (Р1; P), kurdil 'narośl tłuszczu koło nasady ogona u pewnych gatunków owiec' (Bar), chociaż zdarza się, że lud mieszał nazwy obu przypadłości, por. np. buk. курдюк 'хвороба язика коней' (SBH).

Dobrze poświadczone na gruncie języka polskiego, por. kurdziel, daw. kurdzieł, kurdziej, gurdziel, kurdwiel, rzad. gurdwiel wet. 'nazwa ludowa wrzodu lub obrzmienia pod językiem u zwierząt wskutek urazu ciał obcych' (SW II: 641), kurdziel 'choroba bydła i koni: wrzód na języku' (MSGP: 119), znany też gwarom słowackim, por. kurdel'(kurdial) 'choroba jazyka hovädzieho dobytka al. koní' (SSN I: 911), i językowi czeskiemu, por. kurděj, kurděje med. 'szkorbut, gnilec' (Machek: 308; SCP: 274).

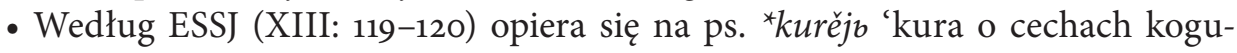
ta, kura hermafrodyta', co pochodne od *kurb 'kogut', “kura 'kura', wzbogacone o wstawne ekspresywne - $d$ '. Co do znaczenia, por. pol. kurzajka 'rodzaj brodawki', dial. kurza dupa 'twarda, guzowata narośl skórna; brodawka' (MSGP: 120). Propozycja A. Bańkowskiego dopatrywania się tu złożenia kur(o)dziel raczej nieprawdopodobna (SEBań I: 858).

\section{Skróty}

bojk. - bojkowski; brus. - białoruski; buk. - bukowiński; bułg. - bułgarski; czes. - czeski; dial. - dialektalny; huc. - huculski; lit. - litewski; łemk. - łemkowski; mor. - morawski; naddniestrz. - naddniestrzański; niem. - niemiecki; pol. - polski; ps. - prasłowiański; ros. rosyjski; rum. - rumuński; rzad. - rzadki; sch. - serbsko-chorwacki; scs. - staro-cerkiewno-słowiański; słc. - słowacki; słeń. - słoweński; stpol. - staropolski; tur. - turecki; ukr. - ukraiński; wet. - weterynaryjny; węg. - węgierski; zakarp. - środkowozakarpacki 


\section{Literatura}

AH: A. Hnát, Krátky rusínsky slovník, Trebišov 2003.

AP: A. Pavlešin, Mali rječnik lemkivskog govora ukrajinskog jezika, Zagreb 2007.

BAR: J.A. Rieger, Mały słownik łemkowskiej wsi Bartne, Warszawa 2016.

B-H: A. Bìgunâk, O. Gojsak, Lemkivs'kij slovničok, Ternopil' 1997.

BR: R. Bronikowska, Dawne słownictwo zachodniołemkowskiej gwary Szczawnika koło Krynicy, [w:] J. Rieger (red.), Studia nad słownictwem gwar ukrainskich w Polsce. Łemkowszczyzna i gwary nadsańskie, Warszawa 2002, s. 17-64.

Buffa: F. Buffa, Slovník šarišských nárečí, Prešov 2004.

ČIž: M. Čižmárová, Nárečový slovník Rusínov-Ukrajincov Slovenska, t. I, Prešov 2013.

DAHL: V. Dal', Tolkovyj slovar' živogo velikorusskogo âzyka, t. I-IV, Moskva 1978-1980.

ESBM: V.U. Martynaǔ (red.), Ėtymalagičny sloǔnik belaruskaj movy, t. 1-, Mìnsk 1978-.

ESSJ: O.N. Trubačev (red.), Ettimologičeskij slovar' slavânskih âzykov. Praslavânskij leksičeskij fond, t. 1-, Moskva 1974-.

ESUM: O. Mel’ničuk (red.), Etimologičnij slovnik ukraïns'koï movi, t. 1-6, Kï̈v 1982-2012.

FAL: J. Falkowski, B. Pasznycki, Na pograniczu łemkowsko-bojkowskim. Zarys etnograficzny, Lwów 1935.

H: J. Horoszczak, Słownik łemkowsko-polski, polsko-łemkowski, Warszawa 2004.

HH: Â. Zakrevs'ka (red.), Gucul's'ki govirki. Korotkij slovnik, L'vìv 1997.

HN: V. Gnatûk, Slovarec' menše zrozumilih viraziv, [w:] idem, Etnografičnì materiali z Ugors'koï Rusi, t. VI, „Etnografičnij zbìrnik ”, t. 30, L’vìv 1911, s. 335-350.

Horв: O. Gorbač, Pìvennolemkivs'ka govirka j diâlektnij slovnik sela Krasnij Brìd bl. Medžilaborec' (Prâšìvîina), Mûnhen 1973.

Hrincz: B. Grìnčenko (red.), Slovar' ukraïns'koï movi, t. I-IV, Kiïv 1907-1909.

J: J. Janów, Słownik huculski, oprac. i przygot. do druku J. Rieger, Kraków 2001.

KáLAL: K. Kálal, M. Kálal, Slovenský slovník z literatúry aj nárečí. Slovensko-český differenciálny, Banska Bystrica 1923.

KRÁLIK: L. Králik, Stručný etymologický slovník slovenčiny, Bratislava 2015.

KSSJ: Krátky slovník slovenského jazyka, Bratislava 1989.

ŁyZANec': P. Łyzanec', Vengerskie zaimstvovaniâ v ukrainskih govorah Zakarpat'â. Vengersko-ukrainskie mež"âzykovye svâzi, Budapešt 1976.

MacheK: V. Machek, Etymologický slovník jazyka českého, Praha 1968.

MaKowiecki: S. Makowiecki, Słownik botaniczny łacińsko-małoruski, Kraków 1936.

MSGP: J. Wronicz (red.), Mały słownik gwar polskich, Kraków 2010.

O: M. Oniškevič, Slovnik bojkivs'kih govirok, t. 1-2, Kiïv 1984.

P: P. Pirtej, Korotkij slovnik lemkivs'kih govirok, İvano-Frankìvs'k 2004.

P1: P. Pirtej, Slovnik lemkivs'koï govirki. Materiali dlâ slovnika, Legnica 2001.

PAn: S. Panc'o, N. Lìsnâk, Slovnik prikmetnikovogo leksikonu lemkivs'kih govirok, Ternopìl' 2015.

Pr: M. Prijmak, Lemkivs'kij slovničok (Dokinčennâ), „Rìdna mova” cz. 11, 1934, s. 495-496.

R: J. Rieger, Słownictwo i nazewnictwo łemkowskie, Warszawa 1995.

S: G. Šilo, Naddnistrâns'kij reg’̀onal'nij slovnik, L'vìv - N'û-Jork 2008.

SAB: İ. Sabadoš, Slovnik zakarpats'koï govirki sela Sokirnicâ Husts'kogo r-nu, Užgorod 2008.

SBH: N. Gujvanûk (red.), Slovnik bukovins'kih govirok, Černìvcì 2005.

SCP: J. Siatkowski, M. Basaj, Słownik czesko-polski, wyd. IV, Warszawa 2010. 
SEBAń: A. Bańkowski, Etymologiczny słownik języka polskiego, t. 1-2, Warszawa 2000.

SEBor: W. Boryś, Słownik etymologiczny języka polskiego, Kraków 2005.

SEBR: A. Brückner, Słownik etymologiczny języka polskiego, Kraków 1927.

SESŁ: F. Sławski, Słownik etymologiczny języka polskiego, t. I-V, Kraków 1952-1982.

SGM: J. Wronicz (red.), Słownik gwar małopolskich, t. I-II, Kraków 2016-2017.

Šiš: R. Šišková, Areálová studie slovní zásoby rusínských nářeči východního Slovenska. Diferenční slovník, Praha 2009.

SmoczyńsKi: W. Smoczyński, Słownik etymologiczny języka litewskiego, Wilno 2007.

SON: V. Lêsnova, Slovnik ocinnih nomeniv lûdini v ukraïns'kih dialektah, Lugans'k 2013.

SP: F. Sławski (red.), Słownik prasłowiański, t. I-VIII, Wrocław 1974-2001.

SSN: I. Ripka (red.), Slovník slovenských náreči, t. I-, Bratislava 1994-.

SW: J. Karłowicz, A.A. Kryński, W. Niedźwiecki (red.), Słownik języka polskiego, t. I-VIII, Warszawa 1900-1927.

T: Ê. Turčin, Slovnik sela Tilič na Lemkivŝinì, L’vìv 2011.

TSBM: K.K. Krapìva (red.), Tlumačal'ny sloǔnì belaruskaj movy, t. 1-5, Mìnsk 1977-1984.

VASMER: M. Fasmer, Ėtimologičeskij slovar' russkogo âzyka, t. I-IV, Moskva 1986-1987.

W: İ. Verhratskij, Pro govor galickih lemkiv, L'vìv 1902.

WD: İ. Verhratskij, Pro govor dolivskij, L'vìv 1900.

WSRP: H. Mirska-Lasota, J. Porawska, Wielki słownik rumuńsko-polski, Kraków 2009.

WTSSUM: V. Busel (red.), Velikij tlumačnij slovnik sučasnoï ukraïns'koï movi, Kï̈v - İrpìn' 2001.

WU: İ. Verhratskij, Znadobi dlâ piznanâ ugorsko-ruskih govorìv, L’vìv 1901.

\section{Lemko Etymologies. Part IV \\ Summary}

The present paper is the fourth part in the Lemko etymologies series; analysed in it are words beginning with letter К: кавеніти, кавери, кадивай (кадиваль), карати ся, каренчыти, каслик, кєпешыти ся, кіпнина, кырмак, кырнак, кыртавый, кыявчати, клапеи, клаптош, клеветати, ключы, кобан (кобаня, кобиия), ковырдати, конда (кондя), копьрдати ся, кочюрба, кракоч, кужівка, курділь. Authors attempt to establish the origin of those words, taking into account data from etymological, historical, and dialectal dictionaries of Slavic languages and dialects, as well as from the neighbouring non-Slavic languages, thereby outlining a broad comparative background. They propose additions and corrections to previous etymological findings regarding some of the discussed words. 